\title{
Present climate trends and variability in thermohaline properties of the northern Adriatic shelf
}

\author{
Ivica Vilibić ${ }^{1}$, Petra Zemunik ${ }^{1}$, Jadranka Šepić ${ }^{1}$, Natalija Dunić ${ }^{1}$, Oussama Marzouk ${ }^{2}$, Hrvoje Mihanović ${ }^{1}$, \\ Clea Denamiel ${ }^{1}$, Robert Precali ${ }^{3}$, and Tamara Djakovac ${ }^{3}$ \\ ${ }^{1}$ Institute of Oceanography and Fisheries, Split, Croatia \\ ${ }^{2}$ SeaTech, University of Toulon, Toulon, France \\ ${ }^{3}$ Center for Marine Research, Ruđer Bošković Institute, Rovinj, Croatia
}

Correspondence: Ivica Vilibić (vilibic@izor.hr)

Received: 13 February 2019 - Discussion started: 18 February 2019

Revised: 3 September 2019 - Accepted: 15 September 2019 - Published: 17 October 2019

\begin{abstract}
The paper documents seasonality, interannual-todecadal variability, and trends in temperature, salinity, and density over a transect in the shallow northern Adriatic Sea (Mediterranean Sea) between 1979 and 2017. The amplitude of seasonality decreases with depth and is much larger in temperature and density than in salinity. Time series of temperature and salinity are correlated in the surface but not in the bottom layer. Trends in temperature are large (up to $0.6^{\circ} \mathrm{C}$ over 10 years), significant through the area, and not sensitive to the sampling interval and time series length. In contrast, trends in salinity are largely small and insignificant and depend on the time series length. The warming of the area is more during spring and summer. Such large temperature trends and their spatial variability emphasize the importance of maintaining regular long-term observations for the proper estimation of thermohaline trends and their variability. This is particularly important in regions which are key for driving thermohaline circulation such as the northern Adriatic, with the potential to affect biogeochemical and ecological properties of the whole Adriatic Sea.
\end{abstract}

\section{Introduction}

Although it is shallow, with depths lower than $80 \mathrm{~m}$ and limited dimensions (ca. $150 \mathrm{~km} \times 250 \mathrm{~km}$ ), the northern Adriatic shelf (Fig. 1) has been recognized early as an important area in the Mediterranean, as a number of important ocean processes occur there. These include (1) tides, which are strongly amplified due to their near resonance with the
Adriatic eigenoscillations and surpass $1 \mathrm{~m}$ at the northernmost part of the Adriatic (Janeković and Kuzmić, 2005; Vilibić et al., 2017); (2) storm surges, which are generated by a strong and persistent sirocco wind and can flood coastal cities in the northern Adriatic, like Venice (Trigo and Davies, 2002; Međugorac et al., 2018); (3) a substantial freshwater discharge (Raicich, 1996), which drives the surface branch of the Adriatic Sea thermohaline circulation, outflowing along the western coast and causing the counterflow along the eastern coastline that brings saline Levantine Intermediate Water (LIW) all the way to the northern Adriatic (Orlić et al., 1992; Artegiani et al., 1997); and (4) dense water formation (Bergamasco et al., 1999; Beg-Paklar et al., 2001; Mihanović et al., 2013), which occurs during the wintertime cold bora outbreaks at the shelf (Grisogono and Belušić, 2009), resulting in the generation of the densest Mediterranean water mass, the North Adriatic Dense Water (NAdDW; Zore-Armanda, 1963). The NAdDW spreads over the deep Adriatic layers as a density current (Artegiani and Salusti, 1987) and ventilates the middle and southern Adriatic depressions (Vilibić, 2003; Bensi et al., 2013).

All of the quoted processes are, to a certain extent, influenced by climate changes; thus a prerequisite for proper assessment of their variability is long-term monitoring. Due to their quasi-resonant nature, the tides are sensitive to changes in mean sea level; i.e. a sea level rise of $2 \mathrm{~m}$ would increase the major diurnal tide $K_{1}$ by $25 \%$ and decrease the major semidiurnal tide $M_{2}$ by $10 \%$ in the northern Adriatic (Lionello et al., 2005). The Adriatic storm surges are sensitive to the intensity and frequency of cyclones, projected to de- 


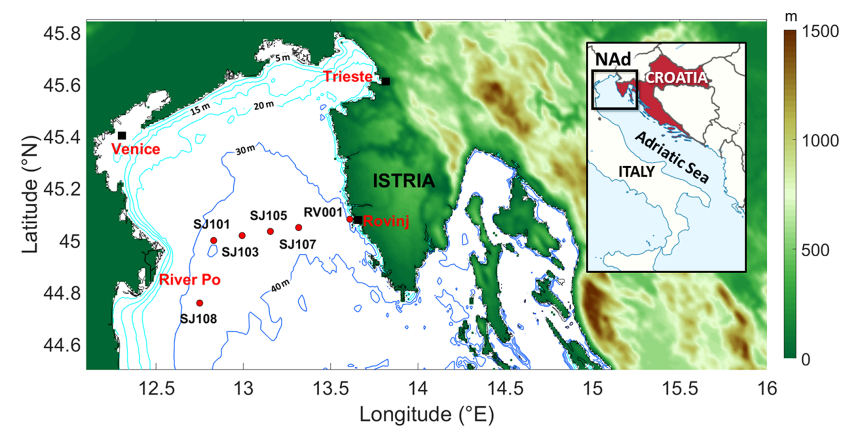

Figure 1. The orography and bathymetry of the northern Adriatic and the location of stations.

crease in frequency but not in peak intensity in the future climate (Androulidakis et al., 2015; Lionello et al., 2017b). Also, a small change of synoptic patterns may change the distribution of storm surge heights along the coastal northern Adriatic (Međugorac et al., 2018). A pronounced warming trend with its maximum in the summer season and a substantial decrease in precipitation, especially in the warm season (Giorgi, 2006; Giorgi and Lionello, 2008; Planton et al., 2012; Branković et al., 2013; Lionello and Scarascia, 2018), is going to affect river discharges in the Adriatic. Yet, the Alpine region is projected to be less influenced by the precipitation decrease, having even an increase in its northern parts (Gao et al., 2006), as a dividing line between the Mediterranean drying regime and the continental wetting regime in precipitation projections is stretching along the northern Adriatic drainage areas (Zampieri et al., 2012). For that reason, freshwater influx to the Adriatic Sea through the northern Adriatic rivers will change with climate, but this will be in terms of seasonality rather than total runoff (Coppola et al., 2014). Last but not least, dense water formation in the Adriatic is found to have a decreasing trend in the present climate, at least as seen on the thermohaline circulation reproduced by ocean climate simulations (Somot et al., 2006) and long-term measurements along the Palagruža Sill transect (Vilibić et al., 2013).

The northern Adriatic Sea is one of the rare Mediterranean regions where a tradition of continuous high-resolution (monthly or bimonthly) monitoring of oceanographic parameters has been preserved over a prescribed set of stations. Such an approach is sparse in the rest of the Mediterranean (Malanotte-Rizzoli et al., 2014). These measurements allow for long-term investigations of northern Adriatic ecosystem variability and trends (Plavšić, 2004; Mozetič et al., 2010; Ivančić et al., 2010; Kraus and Supić, 2011; Marić et al., 2012; Giani et al., 2012; Djakovac et al., 2015; Iveša et al., 2016; Dautović et al., 2017). Previous works also include an analysis of variability and changes of the thermohaline properties (Supić et al., 2004) and their drivers, freshwater discharges, and air-sea fluxes (Supić and Ivančić, 2002). The long-term trends in temperature and salinity over a centen- nial timescale have not been found to be significant in the eastern part of the northern Adriatic shelf (1921-2000, station RV001; Supić et al., 2004), although the deep southern Adriatic exhibits centenarian warming (1911-2009; Lipizer et al., 2014). Yet, the temperature and salinity trends in the last few decades have been found to be significant in different parts of or in the whole Mediterranean Sea (Shaltout and Omstedt, 2014; Grbec et al., 2018; Pastor et al., 2018; Bengil and Mavruk, 2019). This applies to the surface, but it also applies to the deep layers to which warming induced by climate change propagates more slowly (Bethoux et al., 1990; Tsimplis and Baker, 2000; Millot et al., 2006; Cusinato et al., 2018).

The Adriatic Sea in situ ocean observations have also been continuous at the Palagruža Sill transect in the middle Adriatic, since 1952. The Palagruža series has been investigated in a number of studies (i.e. Grbec et al., 2009; Vilibić et al., 2012, 2013; Mihanović et al., 2015), as this transect is located at the key region for water mass exchange between the deep and the shallow Adriatic and Mediterranean regions (Buljan and Zore-Armanda, 1976; Martin et al., 2009). The Palagruža Sill trends indicate a weakening of the AdriaticIonian thermohaline circulation (Vilibić et al., 2013), which is governed by the dense water formation and freshwater discharges in the northern Adriatic, as well as by the inflow of the LIW and the dominant circulation patterns in the Ionian. Yet the northern Adriatic thermohaline measurements, in particular their variability and trends, have not been analysed during the last two decades when accelerated changes in the Mediterranean climate have been found to occur (Lionello et al., 2017a). Our study bridges this research gap, analysing thermohaline variability and trends during the 1979-2017 period with the European Centre for Medium-Range Weather Forecasts (ECMWF) providing an interim reanalysis (ERAInterim). The emphasis is particularly given to the present climate trends and their persistence. Section 2 presents the data and the methods. An analysis of seasonal variance, interannual variability and trends is given in Sect. 3. Finally, Sect. 4 discusses the results and highlights the major findings.

\section{Data and methods}

In situ temperature and salinity data were collected at six stations surveyed mostly monthly or bimonthly between 1979 and 2017: SJ108, SJ101, SJ103, SJ105, SJ107 and RV001 (Fig. 1, from west near Italy to east near Croatia). The samples were taken at 0, 5, 10, 20, 30 and $2 \mathrm{~m}$ above the seabed. The temperature was measured by protected reversing thermometers (Richter and Wiese, Berlin; precision $\pm 0.01^{\circ} \mathrm{C}$ ) and by reversing digital thermometers (SiS RTM 4002; precision $\pm 0.003^{\circ} \mathrm{C}$ ) attached to the Niskin bottles. Salinity was determined using high-precision laboratory salinometers with an accuracy of \pm 0.01 . For months with two or 


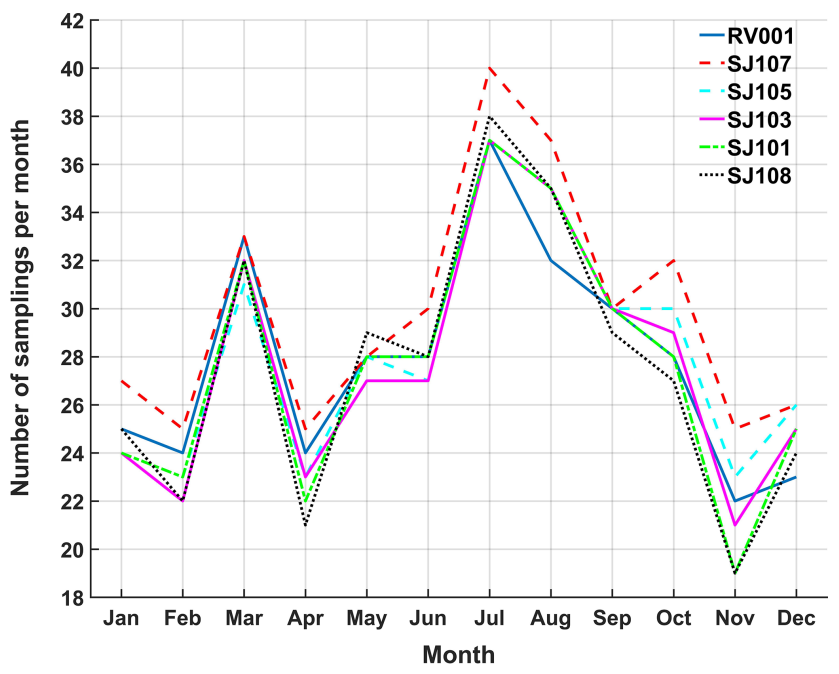

Figure 2. Total number of samplings per month during the studied period (1979-2017).

more measurements, the averages were used in analyses. The number of samples in a month varied between 19 and 25 in November and 37 and 40 in July, with sampling more frequent during the summer season and in March than during the rest of the year (Fig. 2).

All data were checked for quality (1) by using min-max thresholds $\left(4-32{ }^{\circ} \mathrm{C}\right.$ for temperature, $10-40$ for salinity) defined by the long-term climatology of the northern Adriatic (Artegiani et al., 1997; Lipizer et al., 2014), (2) by ensuring that the vertical stability of the water column has been preserved, and (3) by visual checking and comparing each data point to its neighbours in both space (measurements at neighbouring depths and stations) and time. Potential density anomalies (PDAs) with a reference pressure of zero were estimated using algorithms defined by the International Thermodynamic Equation of Seawater - 2010 (TEOS-10, http://www.teos-10.org/, last access: 10 October 2019).

Seasonal changes of all variables were largely removed from each series by fitting annual (12 months) and semiannual (6 months) cosine functions to the data. The procedure was separately applied for each station, depth and variable. Due to the discontinuous nature of the monthly measurements $\left(X_{t}\right)$ used in this study, the removal of the annual cycle from the time series via a classical Fourier analysis or a low-pass filter could not be directly applied. The annual cycle $\left(S_{t}\right)$ was thus obtained with a general harmonic regression model (Chatfield, 2004; Wilks, 2011) applied to the de-trended signal $\left(Y_{t}=X_{t}-T_{t}-\mu_{t}\right.$, where $T_{t}$ and $\mu_{t}$ are respectively the linear trend and the mean estimated for the raw signal $X_{t}$ ) and using cosine and sine functions for two Fourier frequencies $\left(f_{1}=\frac{1}{12}, f_{2}=\frac{1}{6}\right): S_{t}=$ $\sum_{i=1}^{2}\left[a_{i} \cos \left(2 \pi f_{i} t\right)+b_{i} \sin \left(2 \pi f_{i} t\right)\right]$, where $a_{i}=R_{i} \cos \left(d_{i}\right)$ and $b_{i}=-R_{i} \sin \left(d_{i}\right)$, with $R_{i}$ and $d_{i}$ being the amplitude and the phase of the signal, respectively. The remaining signal, $Z_{t}=X_{t}-S_{t}$, is referred to as the residual series and is used for the trend analysis. The residual series kept a part of the monthly signal, which in the case of strong seasonal oscillations (like in the northern Adriatic) is normally much lower than the annual cycle (see Sect. 3.1).

The trend significance was estimated by the MannKendall nonparametric test.

\section{Results}

\subsection{Seasonal cycle, variance and residual averages}

Seasonal changes in the surface layer are quite large (Fig. 3), with the surface temperature reaching a minimum of $8-9^{\circ} \mathrm{C}$ in February and a maximum of $25-26^{\circ} \mathrm{C}$ in August. The monthly max-min range in the surface temperature is slightly larger on the western (SJ101) than on the eastern (RV001) section of the transect, due to stronger haline-driven stratification that decreases the rate of vertical heat exchange between the surface and bottom layers. For the same reason, the monthly range of bottom temperature is lower on the western side than on the eastern side of the transect. Surface salinity peaks during wintertime (37.3 at SJ101 in January and 38.0 at RV001 in February), when the freshening by rivers is restricted to the western coastline (Artegiani et al., 1997), and it decreases (32.3 at SJ101 in May and 36.3 at RV001 in July) following the spring maximum in river discharges (Raicich, 1996). Bottom salinity does not change much, having values around 38.0 throughout the year. The PDA seasonal cycle is mostly affected by temperature changes on the eastern side of the transect (up to $70 \%$ of PDA surface change is due to temperature changes, when the linear equation of the state of seawater is applied) and by salinity changes on the western side of the transect (up to $55 \%$ of PDA surface change is due to salinity changes). The largest PDA values are measured in February, with near-bottom values between 29.4 and $29.5 \mathrm{~kg} \mathrm{~m}^{-3}$ along the transect. These numbers indicate the generation of the NAdDW over most of the northern Adriatic, filling the northern Adriatic shelf before flowing to the southeast along the western shelf break (Artegiani and Salusti, 1987; Janeković et al., 2014).

On the eastern side of the transect, the seasonal changes have a much larger amplitude than the residual variations for both surface and bottom temperatures (Fig. 4). The same applies to the PDA. However, salinity, particularly for the bottom layer, is not as strongly dominated by the seasonal variations. The dominance of the seasonal signal in the temperature changes is emerging from percentages of the annual and semi-annual cycle variance versus total variance (Fig. 5). This value is above $90 \%$ at the surface and is not lower than $75 \%$ near the bottom. The variance of the salinity seasonal series surpasses $30 \%$ at the surface of the eastern section of 

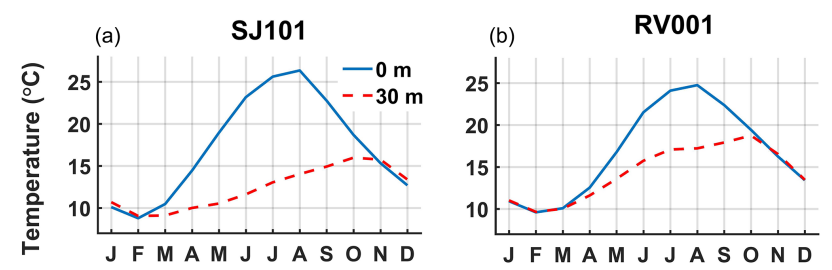
(c)
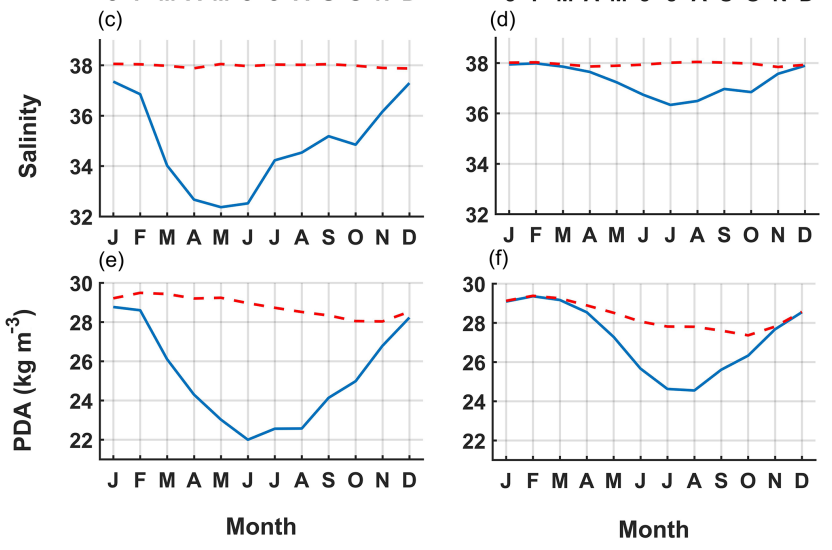

Figure 3. Seasonal course of temperature, salinity and PDA at SJ101 (a, c, e) and RV001 (b, d, f).
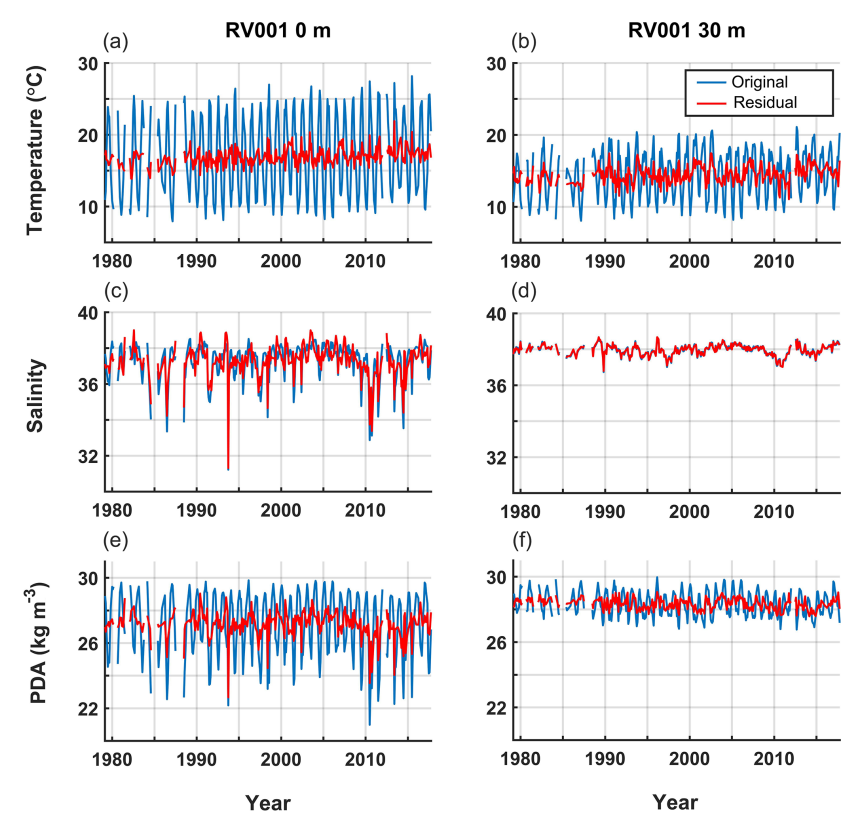

Figure 4. Original series and residual component of the temperature, salinity and PDA series at the surface $(0 \mathrm{~m} ; \mathbf{a}, \mathbf{c}, \mathbf{e})$ and bottom (30 m; b, d, f) of RV001.

the transect and $20 \%$ at the surface of the western section of the transect (station SJ108). This implies that the transport of the Po River waters towards the eastern coastline has a larger seasonality, whilst station SJ108 is affected by the river plume uniformly throughout the year (Kourafalou, 1999). In the bottom layer, the variance of the salinity seasonal series is low $(<5 \%)$, indicating a dominance of processes on an

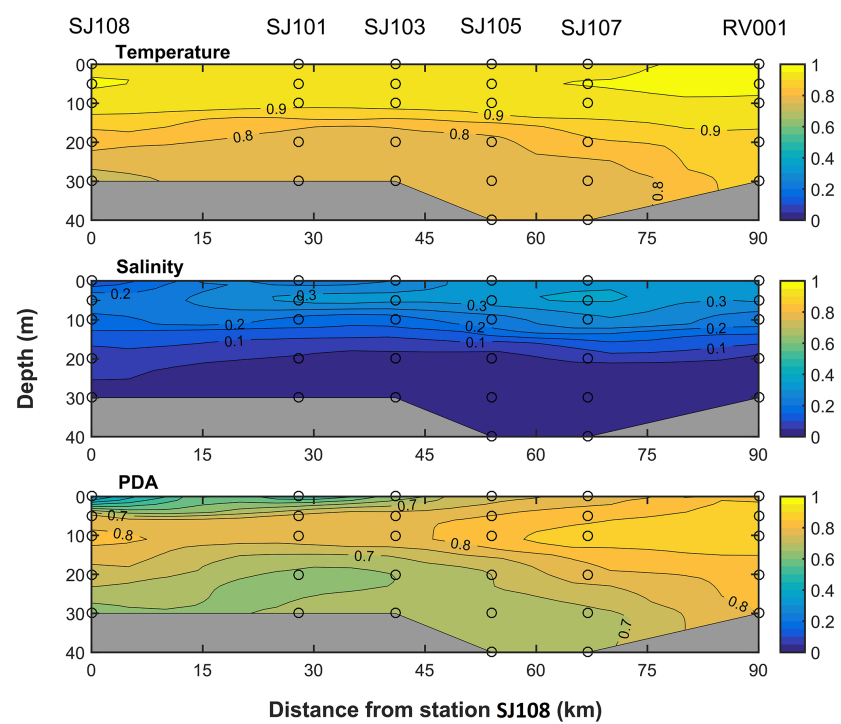

Figure 5. Ratio between the seasonal and total variance of temperature, salinity and PDA.
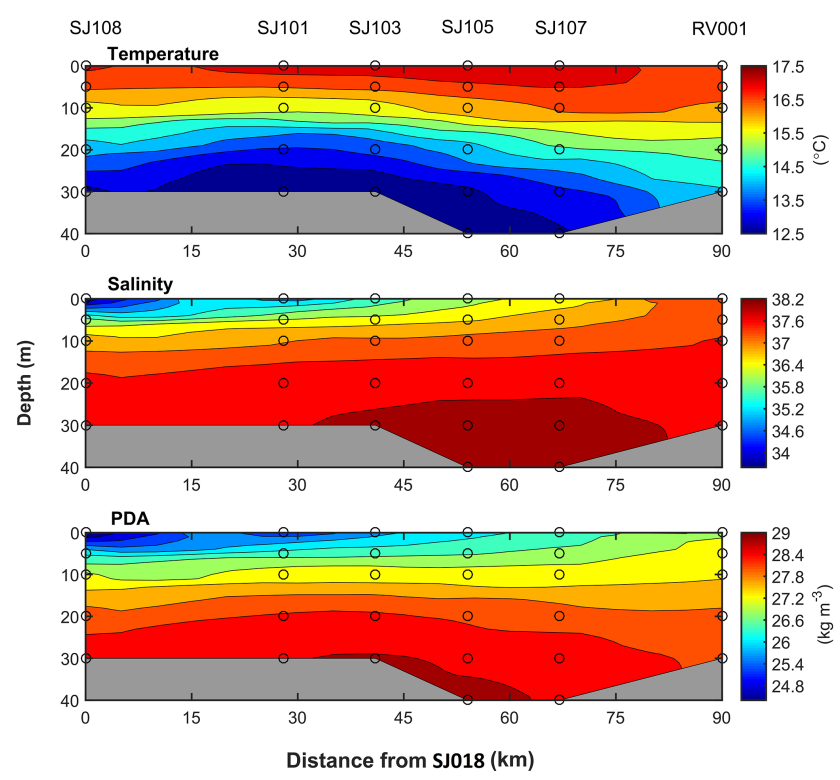

Figure 6. Mean temperature, salinity and PDA values, estimated from the residual series, across the Rovinj-Po transect.

interannual-to-decadal timescale over a seasonal timescale as well as transient changes occurring over a period of a few months. The PDA seasonal variance is affected by both temperature and salinity and is largest in the subsurface layer of the eastern side of the transect $(80 \%-90 \%)$, while it varies between $60 \%$ and $70 \%$ at the bottom of the western side of the transect.

The temperature averages estimated from the residual series (Fig. 6) exhibit a substantial decrease with depth. This is the consequence of (1) cold and dense waters generated during winter residing at the bottom and increasing stratification 
of the water column through the rest of the year and (2) a flooding of the northern Adriatic by waters of low salinity during most of the year. The flooding of the whole Rovinj-Po transect with low-salinity waters coming from the northern Adriatic rivers is reflected in the mean salinity distribution, with the average salinity lower by about 4.0 at the surface than at the bottom off the Po River mouth (station SJ108) and by about 0.6 at the RV001 station. Further on, surface salinity is lower on the western side (33.7 on average at SJ108) than on the eastern side (37.3 on average at RV001) of the transect. The maximum salinity is documented in the nearbottom layers of stations SJ107 through SJ105, indicating the area where the largest advection of saline waters from the southeast is occurring. The PDA distribution along the transect predominantly reflects the effects of salinity in the surface layer and of both temperature and salinity in the bottom layer, with the densest waters residing at the bottom of the central and western sections of the transect (stations SJ105 to SJ101).

\subsection{Interannual variability}

Hovmöller plots of residual temperatures, salinity and the PDA series at stations RV001 and SJ101 (Fig. 7) show a strong interannual signal, both in the surface and bottom layers. An overall increase in temperature at all stations can be visually detected, with prolonged cooler periods in the bottom layer at the beginning of the series (e.g. 1983-1987) and shorter periods of above-average temperatures more frequent in the second part of the series (e.g. 2000-2001, 2007 and 2014). Regarding variations of the residual salinity series, they seem to be a combination of interannual (1-3 years) and quasi-decadal variability (5-10 years). Prolonged periods of higher salinity (e.g. 1987-1991 and 2002-2008), interrupted by shorter periods of lower salinity (e.g. 1984-1986, 19911998 and 2009-2015), all superimposed with interannual variability, can be noticed. Residual PDA interannual-todecadal changes range between $27.2 \mathrm{~kg} \mathrm{~m}^{-3}$ at station $\mathrm{SJ} 103$ and $29.7 \mathrm{~kg} \mathrm{~m}^{-3}$ at station SJ105 near the bottom (30 m). By applying a linear equation of the state of seawater, it follows that ca. $80 \%-90 \%$ and ca. $55 \%$ of residual PDA surface and bottom change, respectively, are due to residual salinity changes on average over the transect. Minimum densities are reached in the periods 1993-1995, 2000-2002 and 20072015, while the highest residual PDA values are observed in the period 2003-2005. The last period matches the ending years of a strong cyclonic Adriatic-Ionian Bimodal Oscillating System (BiOS) regime (1998-2006; Mihanović et al., 2015; see more explanations and discussion in Sect. 4).

Temperature and salinity in the surface layer $(0 \mathrm{~m})$ are correlated at $95 \%$ at all stations but SJ108. An increase in temperature is associated with a decrease in salinity and vice versa. Yet temperature and salinity are not correlated at $95 \%$ in the bottom layer $(30 \mathrm{~m})$, except at station RV001. The variability of residual temperatures is presumably predominantly
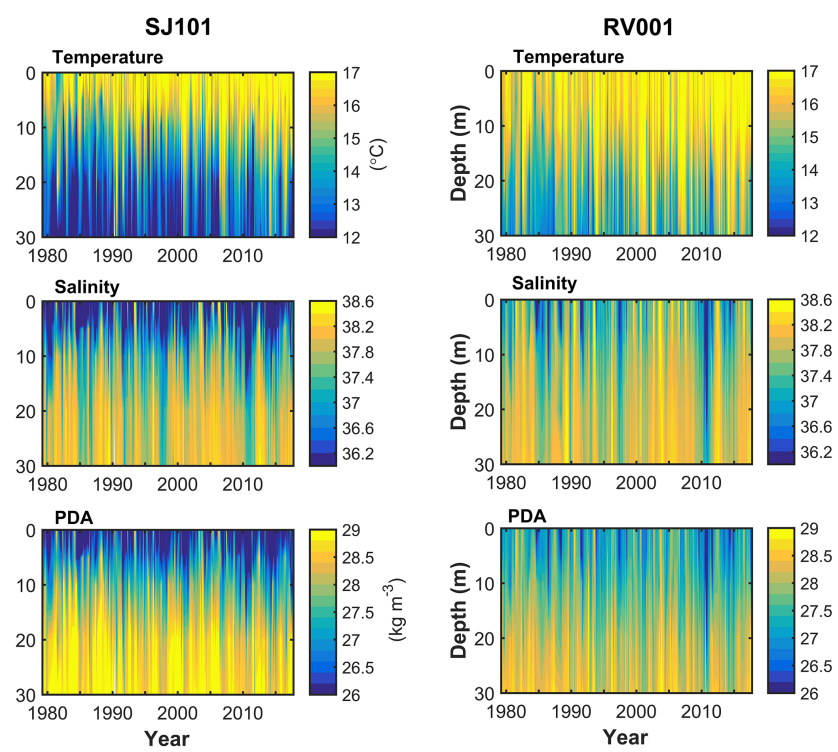

Figure 7. Hovmöller plots of temperature, salinity and PDA at SJ101 and RV001. The seasonal cycle has been removed.

a result of the direct forcing from the atmosphere associated with the hemispheric patterns that are known to influence central Mediterranean temperatures and precipitation (like the East Atlantic pattern; Ionita et al., 2015; Scorzini et al., 2018). The bottom variability of residual salinity is likely largely due to the advection of salt from the southeast through the Adriatic-Ionian thermohaline circulation (Orlić et al., 2006).

\subsection{Trends}

Temperature, salinity and PDA trends estimated on residual annual averages, and presented in Fig. 8, reveal an extensive and statistically significant heating of the entire water column over the whole transect. Trends range from 0.1 to $0.6^{\circ} \mathrm{C}$ over 10 years, reaching a maximum value off the Po River mouth at the bottom of station SJ108. Positive salinity and PDA trends at this station are also large in the surface layer and small and even opposite in the bottom layer. This indicates a weakening of the stratification south of the Po River delta and implies that these higher-than-average temperature bottom trends might be due to an increase of heat transfer towards the bottom in the area. Temperature trends are lowest on the eastern section of the transect $\left(0.1-0.2^{\circ} \mathrm{C}\right.$ over 10 years), where an inflow of waters from the middle Adriatic occurs (Franco et al., 1992; Orlić et al., 1992; Artegiani et al., 1997).

Salinity annual trends are mostly insignificant over the transect. In addition to station SJ108, a significant increase in salinity is also documented at the surface of station SJ107, indicating a mild increase in salinity along the eastern part of the section. The increase is presumably a result of a combination of persistent salting of the middle and southern Adri- 

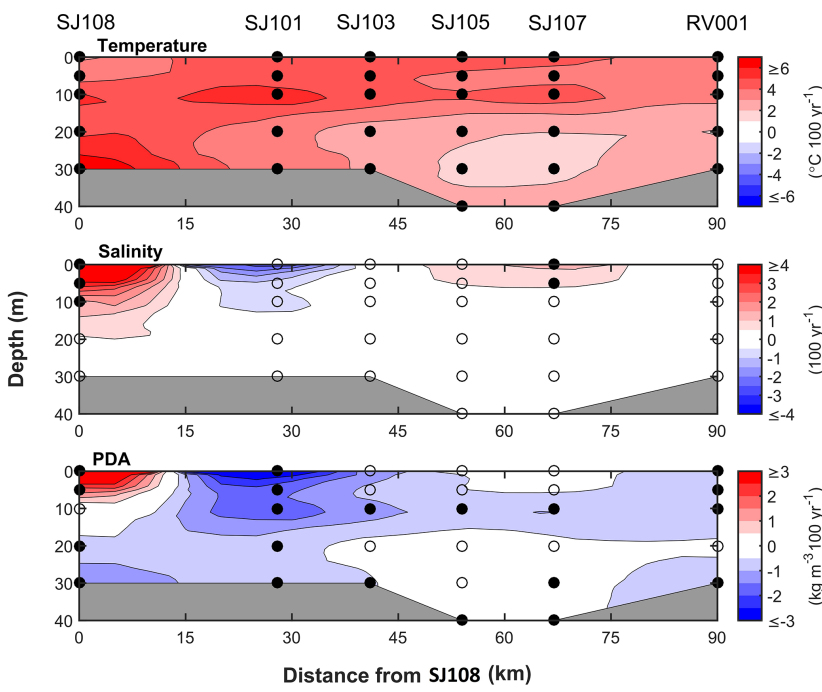

Figure 8. Annual trends in residual temperature, salinity and PDA. Filled circles denote trends with a significance level of $95 \%$.

atic (Vilibić et al., 2013; Lipizer et al., 2014) advected towards the northern Adriatic and of effects of freshwater influx from the northern Adriatic rivers. Interesting surface salinity trends are found off the Po River mouth, with a negative but insignificant trend at SJ101 and a positive and significant trend at SJ108 ( $>0.6$ over 10 years). As both stations are largely influenced by the Po River plume (Kourafalou, 1999), which is characterized by a minimum of salinity in the surface layer (Fig. 3), these trends indicate a change in the Po River dynamics over the examined period; i.e. the plume has been restricted more towards the east and over station SJ101 during the recent decades, while it spread more to the south and over station SJ108 during the 1980s and 1990s.

The bipolar surface structure in trends off the Po River mouth is also detectable from the PDA, while trends over the rest of the transect are both thermally driven and halinedriven. For that reason, the PDA trends are mostly negative over the transect, with rates from -0.3 to $-0.1 \mathrm{~kg} \mathrm{~m}^{-3}$ over 10 years.

Trends in residual temperature, salinity and PDA differ between months. January temperature trends (Fig. 9) are positive, with a maximum in bottom layers at the central part of the transect and at station $\mathrm{SJ} 108\left(>0.4{ }^{\circ} \mathrm{C}\right.$ over 10 years). The salinity trend in January follows the temperature trend in the central section of the transect, indicating an increased rate of advection of the middle Adriatic waters to the northern Adriatic. Trends in summer months, in particular July, have a more complex spatial structure due to baroclinicity. Temperature trends surpass $0.6^{\circ} \mathrm{C}$ over 10 years at the very surface and off the Po River delta, while they are insignificant and even opposite at the bottom of the central and eastern parts of the transect. Such a distribution indicates that a vertical transfer of heat was reduced in the central and eastern sections of the transect, resulting in the accumulation of heat

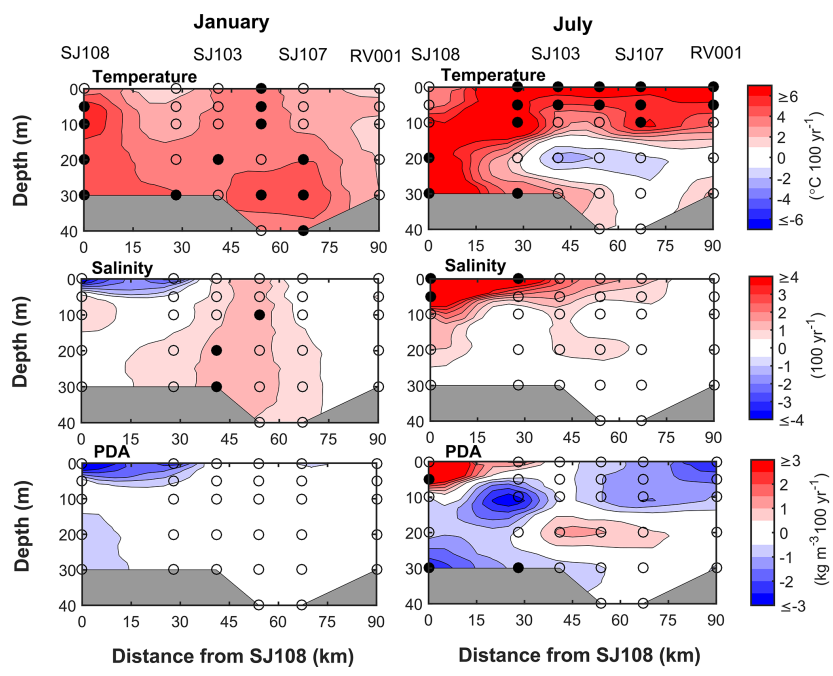

Figure 9. January and July trends in residual temperature, salinity and PDA. Filled circles denote trends with a significance level of $95 \%$.

energy close to the surface. In contrast, temperature trends are largest at the bottom of station SJ108, where more heat transfer to the bottom is presumably allowed by the increased surface salinity and therefore reduced vertical stratification. The salinity trend in July is positive in the western part of the section, peaking at station SJ108 (0.86 over 10 years).

The trends estimated for a month (Fig. 10) reveal that trends are more intense and more significant during the spring and summer months. The largest temperature trends on the eastern side of the transect (RV001) are documented between April and August: in the bottom layer from April through May and in the surface layer between July and August. The bottom trends go to near-zero values between July and November, revealing the stability of the weak vertical exchange of heat due to increased stratification and lowered mixing during late summer and autumn. These trends also reflect trends in air temperature which are larger during the summer and smaller during the winter in the region (Shohami et al., 2011; Bartolini et al., 2012). A secondary maximum in temperature trends on the eastern side of the transect occurs in December. Temperature trends at SJ101 are similar to trends at RV001, but they are even higher during spring and summer (occasionally $>0.8^{\circ} \mathrm{C}$ over 10 years), reflecting coherent seasonal changes over most of the transect. Yet temperature trends at $\mathrm{SJ} 108$ are different, with a maximum restricted to depths higher than $10 \mathrm{~m}$ during the spring and summer months.

Salinity trends present large differences between the eastern and the western sides of the transect. Trends are insignificant on the eastern side of the transect, weakly negative in spring, and positive in summer months (only in surface layers) and in December. In contrast, salinity trends are strongly negative at the surface of SJ101 during most of the year 

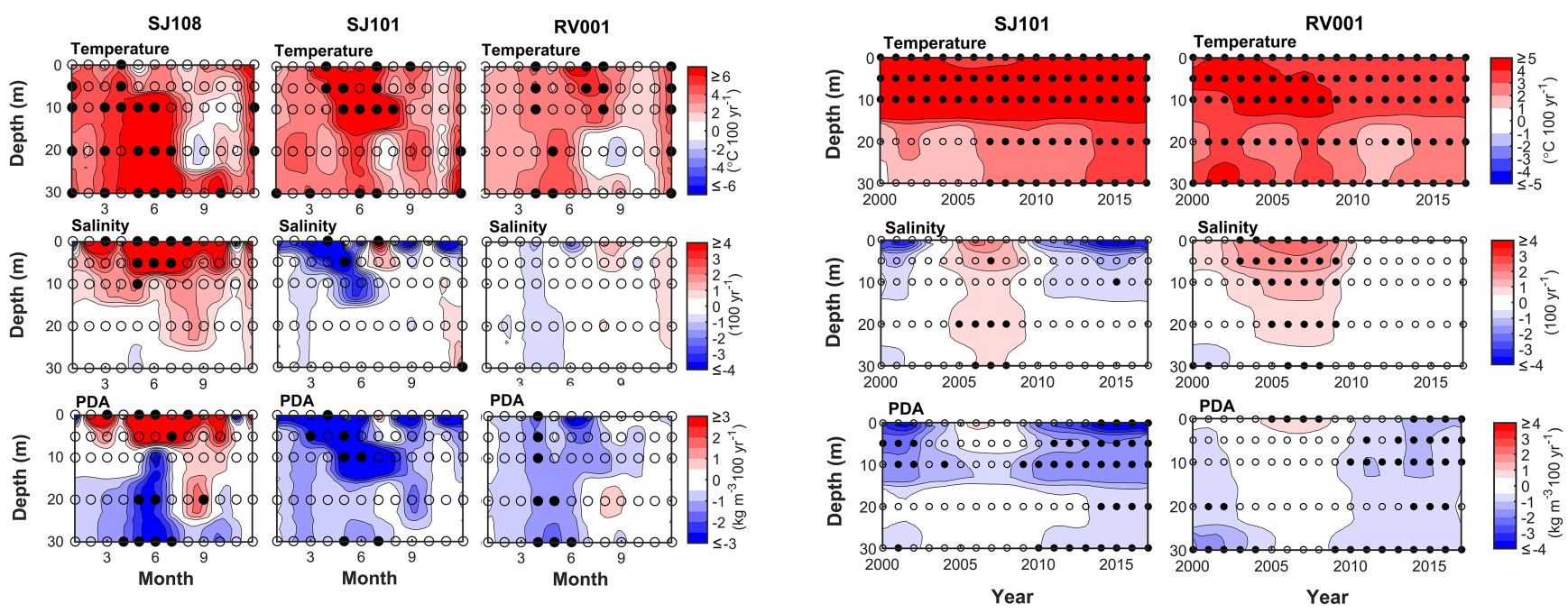

Figure 10. Distribution of monthly trends in residual temperature, salinity and PDA at SJ108, SJ101 and RV001. Filled circles denote trends with a significance level of $95 \%$.

(Fig. 10; $<-0.4$ over 10 years), indicating positive trends in offshore expansion of the Po River plume. Simultaneously, salinity trends are strongly positive at the surface of SJ108 (occasionally $>0.7$ over 10 years).

PDA trends are negative at most of the transect in all months, except at the surface layers of station SJ108. PDA decrease, although not significant, is evident in the winter months (January-February), during which the NAdDW is generated in the northern Adriatic (Zore-Armanda, 1963; Artegiani et al., 1997; Mihanović et al., 2013). The $30 \mathrm{~m}$ February PDA trends range between $-0.11 \mathrm{~kg} \mathrm{~m}^{-3}$ at SJ101 and $-0.08 \mathrm{~kg} \mathrm{~m}^{-3}$ over 10 years at RV001. The period in which the NAdDW spreads to the middle and southern Adriatic, March-June, is characterized by even more negative PDA trends, driven by both temperature and salinity trends.

As the time series are relatively short, it is a question of whether the trends are sensitive to the choice of the sampling interval or are persistent regardless of the sampling interval. For temperature, trends are persistent (Fig. 11), significant and change little over the whole transect, regardless of the inclusion of recent data in the analysis (for the last 17 years). In contrast, salinity trends are substantially dependent on the data interval. For example, salinity trends are significantly positive along the eastern section of the transect for the data intervals between 1979 and the 2000s. However, the trends became insignificant when series are extended to the 2010s. Trends contrast even more for stations off the Po River mouth, where surface trends switch from negative to positive and then to negative with a changing interval (1979 to the early 2000s vs. 1979 to the mid-2000s and late 2000s vs. 1979 to the 2010s). Therefore, interannual-to-decadal variability of the Po River freshwater outflow may substantially alter the salinity trends in the northern Adriatic. That also refers to the PDA trends, sensitivity to the length of the ex-

Figure 11. Sensitivity of trend estimates to the length of the series at the stations SJ101 and RV001. The trends are estimated between 1979 and the year indicated on the $x$ axis. Filled circles denote trends with a significance level of $95 \%$.

amined time series of which is predominantly influenced by salinity changes in the surface layer. Yet the temperature effect keeps PDA trends more stable and mostly significantly negative in the bottom layer.

However, an uneven sampling through a year was conducted over the time interval, with more data gaps present in the first 11 years of monitoring (1979-1989). This particularly applies to autumn, when the maximum in temperature is present in near-bottom layers ( $30 \mathrm{~m}$; Fig. 4). To test if these gaps might affect the annual trend computation, the gaps were mirrored to the last 11 years of measurements (20072017) before the trend estimates. More precisely, the data gap present in 1979 at a certain station, depth and parameter is imposed onto the 2017 data by removing the respective values. The same is done in that gaps in 1980 are imposed onto the 2016 data, etc. Then, the annual trends are recomputed (not shown). The temperature trend shows a slight decrease, up to $10 \%$ at most of the transect, and greater decrease (about $20 \%$ ) is shown at $30 \mathrm{~m}$ for stations SJ105 and SJ108. Yet the overall distribution of temperature trends and of their significance over the transect remains the same. Salinity trends were not affected much by the mirroring, while the PDA trends resemble a small and not significant decrease over the transect driven by the decrease in temperature trends. 


\section{Discussion and conclusions}

The study reveals several important conclusions coming from the presented analysis of the multidecadal temperature, salinity and density dataset measured in the northern Adriatic between 1979 and 2017.

1. Although the northern Adriatic is quite shallow, its vertical stratification is persistent through most of the year (March-November) due to seasonal heating and freshening by a substantial river inflow.

2. Interannual-to-decadal changes in bottom temperature and salinity are not correlated, acting on different timescales and indicating different dominant mechanisms governing their variability; i.e. presumably surface heat fluxes and the advection of water masses mostly drive temperature and salinity changes, respectively.

3. Temperature trends are strongly positive, significant, and persistent in time all over the investigated region; slightly overestimated by a change in the sampling strategy over seasons; and larger near the surface and during spring and summer over most of the investigated area and seasons.

4. Salinity trends are small and mostly insignificant, changing with the data interval used for the trend computation, whilst reflecting changes in the plume dynamics of the major Adriatic river, the Po River.

5. From surface salinity trends at stations SJ101 and SJ108, it can be hypothesized that the transport of freshwater has been reduced towards the southeast along the coast during the investigated period and increased (or remained the same) towards the east. A consequence of this may be an increase in eddy kinetic energy and in residence time of waters in the northernmost part of the Adriatic.

6. Wintertime PDA trends indicate that lighter dense waters were generated in the northern Adriatic during recent decades, predominantly due to temperature changes.

Our observed temperature trends are slightly higher than the average sea surface temperature trends in the Mediterranean in the examined period, which are also found to peak in summer (Shaltout and Omstedt, 2014; Pastor et al., 2018). The largest trend derived from satellites (1982-2016; Pastor et al., 2018) is observed in June, with the rate of $0.43^{\circ} \mathrm{C}$ over 10 years over the whole Mediterranean and ca. $0.55^{\circ} \mathrm{C}$ over 10 years over the northern Adriatic. The surface temperature trends estimated in June and derived from in situ measurements at the Rovinj-Po transect (1979-2016) are $0.63-0.85^{\circ} \mathrm{C}$ over 10 years (the exception is SJ108, which is behaving differently, as it is strongly influenced by the Po River plume). The lowest satellite-derived trends in the northern Adriatic are determined for October and equal to approximately $0.06^{\circ} \mathrm{C}$ over 10 years versus $0.15-0.30^{\circ} \mathrm{C}$ over 10 years as observed at the northern Adriatic transect. Overall, both satellite-derived and in situ-derived sea surface temperature trends reach their maximum values in summer (June-July), while they are lowest in October and JanuaryFebruary. Such large temperature trends in the northern Adriatic and in the examined period might be due to (1) much shallower thermocline in the northern Adriatic than in the rest of the Adriatic and Mediterranean (Franco et al., 1992; Artegiani et al., 1997; Lipizer et al., 2014), resulting in a larger accumulation of heat energy near the surface, and (2) a consequence of atmospheric teleconnection processes acting on a larger spatial and temporal scale, like the Atlantic Multidecadal Oscillation (AMO; Knight et al., 2006), which has been found to be responsible for half of the sea surface temperature trend in the Mediterranean (Marullo et al., 2011; Skliris et al., 2012; Macias et al., 2013). Regarding the rest of the Adriatic, the literature implies that sea surface temperature had a negative trend in the coastal eastern Adriatic between 1960 and 1975, while this trend was strongly positive between 1979 and $2015\left(0.23-0.32^{\circ} \mathrm{C}\right.$ over 10 years; Grbec et al., 2018). For that reason, in situ sea surface temperature trends obtained over the middle Adriatic transversal transect between 1952 and 2010 (Vilibić et al., 2013) were found to be much lower, about $0.1{ }^{\circ} \mathrm{C}$ over 10 years along the northern section of the transect. Yet these trends were much stronger (about $0.25^{\circ} \mathrm{C}$ over 10 years) along the western side of the middle Adriatic transect. Regardless of decadal and multidecadal oscillations, the temperature trends in the whole Mediterranean were positive during the 19502015 period (Iona et al., 2018). The northern Adriatic trends follow all of these findings.

Differently, the Adriatic salinity fluctuations have been largely affected by the Adriatic-Ionian Bimodal Oscillating System (Gačić et al., 2010), which is reflected in quasidecadal (5-10 years) regime changes in the circulation of the northern Ionian Sea and predominantly driven by the dense water formation in the Adriatic Sea (Gačić et al., 2010, 2014; Mihanović et al., 2015; Reale et al., 2017). The BiOS alters salinity in the Adriatic through the advection of the highly saline and ultraoligotrophic LIW from the Levantine Basin, which prevails during the cyclonic BiOS regime, or the advection of less-saline and nutrient-richer Western Mediterranean waters, which occurs with the anticyclonic BiOS regime. These alterations have been documented to affect the middle and southern Adriatic (Gačić et al., 2010; Mihanović et al., 2015), yet they have not proven to affect the shallow northern Adriatic, which is still considered to be mostly affected by local processes, including a substantial freshwater load by rivers (Franco et al., 1992; Artegiani et al., 1997). Recent investigations on some chemical parameters (Dautović et al., 2017) and bivalve growth (Peharda et al., 2018) 
along the eastern coast of the northern Adriatic have documented a qualitative matching and significant correlations between these variables and the BiOS regimes. Our results support that hypothesis, as prolonged (5-10 years) periods of increased or lowered salinity can be found in the northern Adriatic, lagging behind the BiOS reversals in the northern Ionian Sea for a few years. In order to properly quantify the effects of different local and remote drivers to the northern Adriatic thermohaline variability, further research is needed.

Still, salinity trends in the northern Adriatic are not significant over the investigated period, which differs from trends obtained in the middle Adriatic (Vilibić et al., 2013) or the whole Adriatic (Lipizer et al., 2014) over a longer time interval. Further, an increase in salinity in the Adriatic is found to be the largest of all the Mediterranean basins in both present climate investigations and climate projections (Somot et al., 2006; Iona et al., 2018), whilst the whole Mediterranean is projected to increase in salinity (Vargas-Yanez et al., 2017). Whilst no significant trend in annual freshwater discharge has been documented in recent decades in the northern Adriatic (Zanchettin et al., 2008; Montanari, 2012), the difference in salinity trends between the middle and northern Adriatic reveals a change in the freshwater dynamics in the northern Adriatic. Conclusively, increased stratification in the northern Adriatic and intensified spreading of river waters over the shallow shelf due to increased thermally driven stratification might be one of the processes responsible for the weakening of the Western Adriatic Current and the thermohaline circulation (Vilibić et al., 2013).

This study emphasizes the importance of continuous in situ monitoring of thermohaline and other ocean parameters over a prescribed set of stations and with a satisfactory resolution for climate studies (e.g. She et al., 2016). The resolution of measurements used in our analysis is monthly to bimonthly. These kinds of observations are scarce in the Mediterranean but continuous at two transects in the Adriatic Sea (the northern Adriatic transect and the Palagruža Sill transect). The maintenance of these observations is key to properly assessing climate changes, which might be rapid in coastal areas and might have wider consequences, such as weakening thermohaline circulation, deoxygenating deep regions, changing biogeochemical properties and fluxes, and, in the end, impacting the living organisms and fisheries of a region (Tintore et al., 2013).

Code and data availability. Temperature and salinity data from the northern Adriatic transect are available from the first author upon request.

Author contributions. IV and JŠ developed the idea and the concept of the study. ND, OM, TD and RP checked the quality of the data. PZ, ND, HM and JŠ performed the analyses. PZ and CD created the figures, while IV, JS and CD revised the paper with help from all the authors.

Competing interests. The authors declare that they have no conflict of interest.

Acknowledgements. We appreciate the work of researchers, technicians and the research vessel crew of the Center for Marine Research at the Ruđer Bošković Institute in collecting the temperature and salinity data used in the study. Comments and suggestions raised by three anonymous reviewers are greatly appreciated.

Financial support. This research has been supported by the Croatian Science Foundation (grant no. IP-2016-06-1955).

Review statement. This paper was edited by Markus Meier and reviewed by three anonymous referees.

\section{References}

Androulidakis, Y. S., Kombiadou, K. D., Makris, C. V., Baltikas, V. N., and Krestenitis, Y. N.: Storm surges in the Mediterranean Sea: Variability and trends under future climatic conditions, Dyn. Atm. Oceans, 71, 56-82, https://doi.org/10.1016/j.dynatmoce.2015.06.001, 2015.

Artegiani, A. and Salusti, E.: Field observation of the flow of dense water on the bottom of the Adriatic Sea during the winter of 1981, Oceanol. Acta, 10, 387-391, 1987.

Artegiani, A., Bregant, D., Paschini, E., Pinardi, N., Raicich, F., and Russo, A.: The Adriatic Sea general circulation, part I: air-sea interactions and water mass structure, J. Phys. Oceanogr., 27, 1492-1514, https://doi.org/10.1175/15200485(1997)027<1492:TASGCP>2.0.CO;2, 1997.

Bartolini, G., di Stefano, V., Maracchi, G., and Orlandini, S.: Mediterranean warming is especially due to summer season: Evidences from Tuscany (central Italy), Theor. Appl. Clim., 107, 279-295, https://doi.org/10.1007/s00704-011-0481-1, 2012.

Beg-Paklar, G., Isakov, V., Koračin, D., Kourafalou, V., and Orlić, M.: A case study of bora-driven flow and density changes on the Adriatic shelf (January 1987), Cont. Shelf Res., 21, 1751-1783, https://doi.org/10.1016/S0278-4343(01)00029-2, 2001.

Bengil, F. and Mavruk, S.: Warming in Turkish Seas: Comparative multidecadal assessment, Turkish J. Fish. Aquat. Sci., 19, 51-57, https://doi.org/10.4194/1303-2712-v19_1_06, 2019.

Bensi, M., Cardin, V., Rubino, A., Notarstefano, G., and Poulain, P.M.: Effects of winter convection on the deep layer of the Southern Adriatic Sea in 2012, J. Geophys. Res., 118, 6064-6075, https://doi.org/10.1002/2013JC009432, 2013.

Bergamasco, A., Oguz, T., and Malanotte-Rizzoli, P.: Modelling dense water mass formation and winter circulation in the northern and central Adriatic Sea, J. Mar. Syst., 20, 279-300, https://doi.org/10.1016/S0924-7963(98)00087-6, 1999. 
Bethoux, J. P., Gentili, B., Raunet, J., and Tailliez, D.: Warming trend in the Western Mediterranean deep-water, Nature, 347, 660-662, https://doi.org/10.1038/347660a0, 1990.

Branković, C., Güttler, I., and Gajić-Čapka, M.: Evaluating climate change at the Croatian Adriatic from observations and regional climate models' simulations, Clim. Dynam., 41, 2353 2373, https://doi.org/10.1007/s00382-012-1646-z, 2013.

Buljan, M. and Zore-Armanda, M.: Oceanographic properties of the Adriatic Sea, Oceanogr. Mar. Biol. Ann. Rev., 14, 11-98, 1976.

Chatfield, C.: The Analysis of Time Series: An Introduction, 6th edn, CRC Press, Boca Raton, 2004.

Coppola, E., Verdecchia, M., Giorgi, F., Colaiuda, V., Tomassetti, B., and Lombardi, A.: Changing hydrological conditions in the Po basin under global warming, Sci. Total Environ., 493, 11831196, https://doi.org/10.1016/j.scitotenv.2014.03.003, 2014.

Cusinato, E., Zanchettin, D., Sannino, G., and Rubino, A.: Mediterranean thermohaline response to large-scale winter atmospheric forcing in a high-resolution ocean model simulation, Pure Appl. Geophys., 175, 4083-4110, https://doi.org/10.1007/s00024-0181859-0, 2018.

Dautović, J., Vojvodić, V., Tepić, N., Ćosović, B., and Ciglenečki, I.: Dissolved organic carbon as potential indicator of global change: A long-term investigation in the northern Adriatic, Sci. Total Environ., 587, 185-195, https://doi.org/10.1016/j.scitotenv.2017.02.111, 2017.

Djakovac, T., Supić, N., Aubry, F. B., Degobbis, D., and Giani, M.: Mechanisms of hypoxia frequency changes in the northern Adriatic Sea during the period 1972-2012, J. Mar. Syst., 141, 179189, https://doi.org/10.1016/j.jmarsys.2014.08.001, 2015.

Franco, P. and Michelato, A.: Northern Adriatic Sea: oceanography of the basin proper and of the western coastal zone, in: Marine Coastal Eutrophication, edited by: Vollenweider, R. A., Marchetti, R., and Viviani, R., Elsevier, Amsterdam, https://doi.org/10.1016/B978-0-444-89990-3.50013-4, 1992.

Gačić, M., Borzelli, G. L. E., Civitarese, G., Cardin, V., and Yari, S.: Can internal processes sustain reversals of the ocean upper circulation? The Ionian Sea example, Geophys. Res. Lett., 37, L09608, https://doi.org/10.1029/2010GL043216, 2010.

Gačić, M., Civitarese, G., Kovačević, V., Ursella, L., Bensi, M., Menna, M., Cardin, V., Poulain, P.-M., Cosoli, S., Notarstefano, G., and Pizzi, C.: Extreme winter 2012 in the Adriatic: an example of climatic effect on the BiOS rhythm, Ocean Sci., 10, 513-522, https://doi.org/10.5194/os-10-513-2014, 2014.

Gao, X., Pal, J. S., and Giorgi, F. Projected changes in mean and extreme precipitation over the Mediterranean region from a high resolution double nested RCM simulation, Geophys. Res. Lett., 33, L03706, https://doi.org/10.1029/2005GL024954, 2006.

Giani, M., Djakovac, T., Degobbis, D., Cozzi, S., Solidoro, C., and Fonda Umani, S.: Recent changes in the marine ecosystems of the northern Adriatic Sea, Estuar. Coast. Shelf Sci., 115, 1-13, https://doi.org/10.1016/j.ecss.2012.08.023, 2012.

Giorgi, F.: Climate change hot-spots, Geophys. Res. Lett., 33, L08707, https://doi.org/10.1029/2006GL025734, 2006.

Giorgi, F. and Lionello, P.: Climate change projections for the Mediterranean region, Global Planet. Change, 63, 90-104, https://doi.org/10.1016/j.gloplacha.2007.09.005, 2008.

Grbec, B., Morović, M., Beg Paklar, G., Kušpilić, G., Matijević, S., Matić, F., and Ninčević Gladan, Ž.: The relationship between the atmospheric variability and productivity in the
Adriatic Sea area, J. Mar. Biol. Assoc. U.K., 89, 1549-1558, https://doi.org/10.1017/S0025315409000708, 2009.

Grbec, B., Matić, F., Paklar, G. B., Morović, M., Popović, R., and Vilibić, I.: Long-term trends, variability and extremes of in situ sea surface temperature measured along the eastern Adriatic coast and its relationship to hemispheric processes, Pure Appl. Geophys., 175, 4031-4036, https://doi.org/10.1007/s00024-0181793-1, 2018.

Grisogono, B. and Belušić, D.: A review of recent advances in understanding the meso- and microscale properties of the severe Bora wind, Tellus A, 61, 1-16, https://doi.org/10.1111/j.16000870.2008.00369.x, 2009.

Iona, A., Theodorou, A., Sofianos, S., Watelet, S., Troupin, C., and Beckers, J.-M.: Mediterranean Sea climatic indices: monitoring long-term variability and climate changes, Earth Syst. Sci. Data, 10, 1829-1842, https://doi.org/10.5194/essd-10-18292018, 2018.

Ionita, M., Boroneant, C., and Chelcea, S.: Seasonal modes of dryness and wetness variability over Europe and their connections with large scale atmospheric circulation and global sea surface temperature, Clim. Dynam., 45, 2803-2829, https://doi.org/10.1007/s00382-015-2508-2, 2015.

Ivančić, I., Fuks, D., Najdek, M., Blažina, M., Devescovi, M., Šilović, T., Paliaga, P., and Orlić, S.: Long-term changes in heterotrophic prokaryotes abundance and growth characteristics in the northern Adriatic Sea, J. Mar. Syst., 82, 206-216, https://doi.org/10.1016/j.jmarsys.2010.05.008, 2010.

Iveša, L., Djakovac, T., and Devescovi, M.: Long-term fluctuations in Cystoseira populations along the west Istrian Coast (Croatia) related to eutrophication patterns in the northern Adriatic Sea, Mar. Poll. Bull., 106, 162-173, https://doi.org/10.1016/j.marpolbul.2016.03.010, 2016.

Janeković, I. and Kuzmić, M.: Numerical simulation of the Adriatic Sea principal tidal constituents, Ann. Geophys., 23, 3207-3218, https://doi.org/10.5194/angeo-23-3207-2005, 2005.

Janeković, I., Mihanović, H., Vilibić, I., and Tudor, M.: Extreme cooling and dense water formation estimates in open and coastal regions of the Adriatic Sea during the winter of 2012, J. Geophys. Res.-Oceans, 119, 3200-3218, https://doi.org/10.1002/2014JC009865, 2014.

Knight, J. R., Folland, C. K., and Scaife, A. A.: Climate impacts of the Atlantic Multidecadal Oscillation, Geophys. Res. Lett., 33, L17706, https://doi.org/10.1029/2006GL026242, 2006.

Kourafalou, V. H.: Process studies on the Po River plume, North Adriatic Sea, J. Geophys. Res., 104, 29963-29985, https://doi.org/10.1029/1999JC900217, 1999.

Kraus, R. and Supić, N.: Impact of circulation on high phytoplankton blooms and fish catch in the northern Adriatic (1990-2004), Estuar. Coast Shelf Sci., 91, 198-210, https://doi.org/10.1016/j.ecss.2010.10.021, 2011.

Lionello, P. and Scarascia, L.: The relation between climate change in the Mediterranean region and global warming, Reg. Env. Change, 18, 1481-1493, https://doi.org/10.1007/s10113018-1290-1, 2018.

Lionello, P., Mufato, R., and Tomasin, A.: Sensitivity of free and forced oscillations of the Adriatic Sea to sea level rise, Clim. Res., 29, 23-39, https://doi.org/10.3354/cr029023, 2005.

Lionello, P., Ozsoy, E., Planton, S., and Zanchetta, G.: Climate variability and change in the Mediter- 
ranean region, Global Planet. Change, 151, 1-3, https://doi.org/10.1016/j.gloplacha.2017.04.005, 2017a.

Lionello, P., Conte, D., Marzo, L., and Scarascia, L.: The contrasting effect of increasing mean sea level and decreasing storminess on the maximum water level during storms along the coast of the Mediterranean Sea in the mid 21st century, Global Planet. Change, 151, 80-91, https://doi.org/10.1016/j.gloplacha.2016.06.012, 2017b.

Lipizer, M., Partescano, E., Rabitti, A., Giorgetti, A., and Crise, A.: Qualified temperature, salinity and dissolved oxygen climatologies in a changing Adriatic Sea, Ocean Sci., 10, 771-797, https://doi.org/10.5194/os-10-771-2014, 2014.

Macias, D., Garcia-Gorriz, E., and Stips, A.: Understanding the causes of recent warming of Mediterranean waters. How much could be attributed to climate change?, PLoS One, 8, e81591, https://doi.org/10.1371/journal.pone.0081591, 2013.

Malanotte-Rizzoli, P., Artale, V., Borzelli-Eusebi, G. L., Brenner, S., Crise, A., Gacic, M., Kress, N., Marullo, S., Ribera d'Alcalà, M., Sofianos, S., Tanhua, T., Theocharis, A., Alvarez, M., Ashkenazy, Y., Bergamasco, A., Cardin, V., Carniel, S., Civitarese, G., D’Ortenzio, F., Font, J., Garcia-Ladona, E., Garcia-Lafuente, J. M., Gogou, A., Gregoire, M., Hainbucher, D., Kontoyannis, H., Kovacevic, V., Kraskapoulou, E., Kroskos, G., Incarbona, A., Mazzocchi, M. G., Orlic, M., Ozsoy, E., Pascual, A., Poulain, P.-M., Roether, W., Rubino, A., Schroeder, K., Siokou-Frangou, J., Souvermezoglou, E., Sprovieri, M., Tintoré, J., and Triantafyllou, G.: Physical forcing and physical/biochemical variability of the Mediterranean Sea: a review of unresolved issues and directions for future research, Ocean Sci., 10, 281-322, https://doi.org/10.5194/os-10-281-2014, 2014.

Marić, D., Kraus, R., Godrijan, J., Supić, N., Djakovac, T., and Precali, R.: Phytoplankton response to climatic and anthropogenic influence in the north-eastern Adriatic during the last four decades, Estuar. Coast Shelf. Sci., 115, 98-112, 2012.

Martin, P. J., Book, J. W., Burrage, D. M., Rowley, C. D., and Tudor, M.: Comparison of model-simulated and observed currents in the central Adriatic during DART, J. Geophys. Res., 114, C01S05, https://doi.org/10.1029/2008JC004842, 2009.

Marullo, S., Artale, V., and Santoleri, R.: The SST multidecadal variability in the Atlantic-Mediterranean region and its relation to AMO, J. Climate, 24, 4385-4401, https://doi.org/10.1175/2011JCLI3884.1, 2011.

Međugorac, I., Orlić, M., Janeković, I., Pasarić, Z., and Pasarić, M.: Adriatic storm surges and related cross-basin sea-level slope, J. Mar. Syst., 181, 79-90, https://doi.org/10.1016/j.jmarsys.2018.02.005, 2018.

Mihanović, H., Vilibić, I., Carniel, S., Tudor, M., Russo, A., Bergamasco, A., Bubić, N., Ljubešić, Z., Viličić, D., Boldrin, A., Malačič, V., Celio, M., Comici, C., and Raicich, F.: Exceptional dense water formation on the Adriatic shelf in the winter of 2012, Ocean Sci., 9, 561-572, https://doi.org/10.5194/os-9-561-2013, 2013

Mihanović, H., Vilibić, I., Dunić, N., and Šepić, J.: Mapping of decadal middle Adriatic oceanographic variability and its relation to the BiOS regime, J. Geophys. Res.-Oceans, 120, 56155630, https://doi.org/10.1002/2015JC010725, 2015.

Millot, C., Candela, J., Fuda, J. L., and Tber, Y.: Large warming and salinification of the Mediterranean outflow due to changes in its composition, Deep-Sea Res. I, 53, 656-666, https://doi.org/10.1016/j.dsr.2005.12.017, 2006.

Montanari, A.: Hydrology of the Po River: looking for changing patterns in river discharge, Hydrol. Earth Syst. Sci., 16, 3739 3747, https://doi.org/10.5194/hess-16-3739-2012, 2012.

Mozetič, P., Solidoro, C., Cossarini, G., Socal, G., Precali, R., France, J., Bianchi, F., De Vittor, C., Smodlaka, N., and Umani, S.F.: Recent trends towards oligotrophication of the northern Adriatic: Evidence from chlorophyll a time series, Estuar. Coasts, 33, 362-375, https://doi.org/10.1007/s12237-009-91917, 2010.

Orlić, M., Gačić, M., and La Violette, P. E.: The currents and circulation of the Adriatic Sea, Oceanol. Acta, 15, 109-124, 1992.

Orlić, M., Dadić, V., Grbec, B., Leder, N., Marki, A., Matić, F., Mihanović, H., Beg Paklar, G., Pasarić, M., Pasarić, Z. and Vilibić, I.: Wintertime buoyancy forcing, changing seawater properties and two different circulation systems produced in the Adriatic, J. Geophys. Res.-Oceans, 111, C03S07, https://doi.org/10.1029/2005JC003271, 2006.

Pastor, F., Valiente, J. A., and Palau, J. L.: Sea surface temperature in the Mediterranean: Trends and spatial patterns (1982-2016), Pure Appl. Geophys., 175, 4017-4029, https://doi.org/10.1007/s00024-017-1739-z, 2018.

Peharda, M., Vilibić, I., Black, B.A., Markulin, K., Dunić, N., Džoić, T., Mihanović, H., Gačić, M., Puljas, S., and Waldman, R.: Using bivalve chronologies for quantifying environmental drivers in a semi-enclosed temperate sea, Sci. Rep., 8, 5559, https://doi.org/10.1038/s41598-018-23773-w, 2018.

Planton, S., Lionello, P., Artale, V., Aznar, R., Carrillo, A., Colin, J., Congedi, L., Dubois, C., Elizalde, A., Gualdi, S., Hertig, E., Jacobeit, J., Jorda, G., Li, L., Mariotti, A., Piani, C., Ruti, P., Sanchez-Gomez, E., Sannino, G., Sevault, F., Somot, S., and Tsimplis, M.: The climate of the Mediterranean region in future climate projections, in: Climate of the Mediterranean Region: From the Past to the Future, edited by: Lionello, P., Elsevier Insights, Amsterdam, 449-502, https://doi.org/10.1016/B978-012-416042-2.00008-2, 2012.

Plavšić, M.: Long-term variations of folic acid concentrations in the Northern Adriatic, Environ. Int., 30, 761-767, https://doi.org/10.1016/j.envint.2003.12.010, 2004.

Raicich, F.: On the fresh balance of the Adriatic Sea, J. Mar. Syst., 9, 305-319, https://doi.org/10.1016/S0924-7963(96)00042-5, 1996.

Reale, M., Salon, S., Crise, A., Farneti, R., Mosetti, R., and Sannino, G.: Unexpected covariant behavior of the Aegean and Ionian Seas in the period 1987-2008 by means of a nondimensional sea surface height index, J. Geophys. Res.-Oceans, 122, 8020-8033, https://doi.org/10.1002/2017JC012983, 2017.

Scorzini, A. R., Di Bacco, M., and Leopardi, M.: Recent trends in daily temperature extremes over the central Adriatic region of Italy in a Mediterranean climatic context, Int. J. Clim., 38, E741E757, https://doi.org/10.1002/joc.5403, 2018

Shaltout, M. and Omstedt, A.: Recent sea surface temperature trends and future scenarios for the Mediterranean Sea, Oceanologia, 56, 411-443, https://doi.org/10.5697/oc.56-3.411, 2014.

She, J., Allen, I., Buch, E., Crise, A., Johannessen, J. A., Le Traon, P.-Y., Lips, U., Nolan, G., Pinardi, N., Reißmann, J. H., Siddorn, J., Stanev, E., and Wehde, H.: Developing European operational oceanography for Blue Growth, climate change adaptation and 
mitigation, and ecosystem-based management, Ocean Sci., 12, 953-976, https://doi.org/10.5194/os-12-953-2016, 2016.

Shohami, D., Dayan, U., and Morin, E.: Warming and drying of the eastern Mediterranean: Additional evidence from trend analysis, J. Geophys. Res., 116, D22101, https://doi.org/10.1029/2011JD016004, 2011.

Skliris, N., Sofianos, S., Gkanasos, A., Mantziafou, A., Vervatis, V., Axaopoulos, P., and Lascaratos, A.: Decadal scale variability of sea surface temperature in the Mediterranean Sea in relation to atmospheric variability, Ocean Dyn., 62, 13-30, https://doi.org/10.1007/s10236-011-0493-5, 2012.

Somot, S., Sevault, F., and Déqué, M.: Transient climate change scenario simulation of the Mediterranean Sea for the twentyfirst century using a high-resolution ocean circulation model, Clim. Dynam., 27, 851-879, https://doi.org/10.1007/s00382006-0167-z, 2006.

Supić, N. and Ivančić, I.: Hydrographic conditions in the northern Adriatic in relation to surface fluxes and the Po river discharge rates (1966-1992), Period. Biol., 104, 203-209, 2002.

Supić, N., Grbec, B., Vilibić, I., and Ivančić, I.: Long-term changes in hydrographic conditions in northern Adriatic and its relationship to hydrological and atmospheric processes, Ann. Geophys., 22, 733-745, https://doi.org/10.5194/angeo-22-733-2004, 2004.

Tintore, J., Vizoso, G., Casas, B., Heslop, E., Pascual, A., Orfila, A., Ruiz, S., Martinez-Ledesma, M., Torner, M., Cusi, S., Diedrich, A., Balaguer, P., Gomez-Pujol, L., Alvarez-Ellacuria, A., Gomara, S., Sebastian, K., Lora, S., Beltran, J.P., Renault, L., Juza, M., Alvarez, D., March, D., Garau, B., Castilla, C., Canellas, T., Roque, D., Lizaran, I., Pitarch, S., Carrasco, M.A., Lana, A., Mason, E., Escudier, R., Conti, D., Sayol, J.M., Barcelo, B., Alemany, F., Reglero, P., Massuti, E., Velez-Belchi, P., Ruiz, J., Oguz, T., Gomez, M., Alvarez, E., Ansorena, L., and Manriquez, M.: SOCIB: The Balearic Islands coastal ocean observing and forecasting system responding to science, technology and society needs, Mar. Technol. Soc. J., 47, 101-117, https://doi.org/10.4031/MTSJ.47.1.10, 2013.
Trigo, I. F. and Davies, T. D.: Meteorological conditions associated with sea surges in Venice: A 40 year climatology, Int. J. Clim., 22, 787-803, https://doi.org/10.1002/joc.719, 2002.

Tsimplis, M. N. and Baker, T. F.: Sea level drop in the Mediterranean Sea: An indicator of deep water salinity and temperature changes?, Geophys. Res. Lett., 27, 1731-1734, https://doi.org/10.1029/1999GL007004, 2000.

Vargas-Yanez, M., Garcia-Martinez, M. C., Moya, F., Balbin, R., Lopez-Jurado, J. L., Serra, M., Zunino, P., Pascual, J., and Salat, J.: Updating temperature and salinity mean values and trends in the Western Mediterranean: The RADMED project, Prog. Oceanogr., 157, 27-46, https://doi.org/10.1016/j.pocean.2017.09.004, 2017.

Vilibić, I.: An analysis of dense water production on the North Adriatic shelf, Estuar. Coast Shelf Sci., 56, 697-707, https://doi.org/10.1016/S0272-7714(02)00277-9, 2003.

Vilibić, I., Matijević, S., Šepić, J., and Kušpilić, G.: Changes in the Adriatic oceanographic properties induced by the Eastern Mediterranean Transient, Biogeosciences, 9, 2085-2097, https://doi.org/10.5194/bg-9-2085-2012, 2012.

Vilibić, I., Šepić, J., and Proust, N.: Weakening of thermohaline circulation in the Adriatic Sea, Clim. Res., 55, 217-225, https://doi.org/10.3354/cr01128, 2013.

Vilibić, I., Šepić, J., Pasarić, M., and Orlić, M.: The Adriatic Sea: A long-standing laboratory for sea level studies, Pure Appl. Geophys., 174, 3765-3811, https://doi.org/10.1007/s00024-0171625-8, 2017.

Wilks, D. S.: Statistical methods in the atmospheric sciences, Academic Press, International Geophysics, 100, 2-676, 2011.

Zampieri, M., Giorgi, F., Lionello, P., and Nikulin, G.: Regional climate change in the Northern Adriatic, Phys. Chem. Earth, 4041, 32-46, https://doi.org/10.1016/j.pce.2010.02.003, 2012.

Zanchettin, D., Traverso, P., and Tomasino, M.: Po River discharges: a preliminary analysis of a 200-year time series, Clim. Change, 89, 411-433, https://doi.org/10.1007/s10584-008-9395z, 2008.

Zore-Armanda, M.: Les masses d'eau de la mer Adriatique, Acta Adriat., 10, 5-88, 1963. 